\title{
Chapter 11 \\ Predatory Pricing in Platform \\ Competition: Economic Theory and Indian Cases
}

\author{
Aditya Bhattacharjea
}

\section{Introduction}

Predatory pricing, or pricing below costs in order to drive out one or more rival firms, has a long and convoluted history in both economic theory and competition jurisprudence. This already contentious issue has become even more complicated in the context of the new business models, largely based on information and communications technologies (ICT), that come under the rubric of 'two-sided platforms'. The rise of gigantic ICT platform-based firms like Amazon, Apple, Facebook, Google and Microsoft has disrupted several industries and ignited impassioned debates involving policymakers, regulators, politicians, legal scholars and economists in many countries. Even pro-business conservative politicians, as well as the Economist and the Wall Street Journal have expressed concern about declining competition and the power of these 'tech titans'.

In this chapter, the author first provides a non-technical introduction to the economics of predatory pricing, showing why scholars and competition agencies in the United States (US) and European Union (EU) became increasingly sceptical of the feasibility of such a strategy. He shows how India's old Monopolies and Restrictive Trade Practices (MRTP) Act of 1969 remained oblivious of these developments, and how despite several improvements, the poor drafting of the relevant sections of the Competition Act 2002 creates some unnecessary complications. The chapter then provides a non-technical introduction to the economics of

\footnotetext{
${ }^{1}$ For a compilation of relevant quotations, see Section 2 of Carl Shapiro, 'Antitrust in a Time of Populism' (2018) International Journal of Industrial Organisation, to which the author can add the 20 January 2018 issue of the Economist, whose cover page is titled 'The new titans and how to tame them', with an editorial and a long critical article inside.
}

\footnotetext{
A. Bhattacharjea ( $\square)$

Department of Economics, Delhi School of Economics, University of Delhi, Delhi, India e-mail: aditya@econdse.org

(C) The Author(s) 2018

A. Bharadwaj et al. (eds.), Multi-dimensional Approaches Towards New Technology, https://doi.org/10.1007/978-981-13-1232-8_11
} 
platforms, with several examples that are familiar in the Indian context. Implications are derived for the antitrust treatment of predatory pricing. Finally, the author discusses how the Competition Commission of India (CCI) has dealt with some of these issues, in recent cases which have involved allegations of predatory pricing against the app-based taxi aggregators Ola and Uber, whose rivalry exemplifies platform competition.

\section{Traditional Theories of Predatory Pricing and the Chicago Critique ${ }^{2}$}

A predatory pricing strategy appears simple enough. A firm (the 'predator') temporarily charges a price below its costs. The idea is that its rivals (the 'prey') will either lose their customers, or be forced to match the price reduction, thereby incurring losses that will drive them out of business. The predator can then charge monopoly prices and make up the losses it suffered while it was engaged in predation. Traditional economic analysis, as well as the legal framework in most countries, assumes that only an incumbent firm which already has a large share of the market will be able to benefit from predatory pricing after inducing the exit of its rival(s), who are usually treated as new entrants with small market shares. Until the 1970s, allegations of this kind often persuaded antitrust/competition agencies to act against predation. Thereafter, the growing influence of the so-called Chicago critique made them much more sceptical. Scholars associated with the Law School of Chicago University argued that predatory pricing was unlikely to be a profitable business strategy, for several reasons. First, precisely because it has a large market share, the losses incurred by a dominant firm that sets its prices below its costs will necessarily be larger than those of its intended victims. It might be argued that a predator with superior financial resources (colloquially referred to as 'deep pockets' or a 'long purse') can sustain a period of losses to drive out its rivals. But why can't the prey also raise capital? Chicago adherents demanded a fuller explanation for firms' unequal access to financial resources. In their worldview, there can be few monopoly positions durable enough to allow predators to recoup the profits they must sacrifice during the predatory campaign. If the market is large enough to accommodate more than one firm, an equally efficient prey can re-enter after the predator reverts to above-cost pricing, or other firms could enter, possibly after

\footnotetext{
${ }^{2}$ This section and the next restate and update the discussion in Aditya Bhattacharjea, 'Predation, Protection, and the 'Public Interest' (2000) 35(49) Economic and Political Weekly <http://www. epw.in/system/files/pdf/2000_35/49/Predation_Protection_and_the_Public_Interest.pdf $>$. The author believes that this was the first comprehensive treatment of the law and economics of predatory pricing in the Indian context. Readers interested in the economic literature can refer to the references of that paper.
} 
acquiring the assets of the erstwhile prey. Capital markets should also recognize this, and be prepared to finance firms that might be targeted for predation but are otherwise viable. The predator would then have nothing to show for its sacrificed profits. Finally, it makes more sense for a predator to buy out a rival firm than to engage in a mutually destructive price war.

Each of these Chicago School arguments is designed to show that predation is irrational (that is, it does not maximize profits, taking into account both the original sacrifice and the subsequent uncertain recoupment), and to economists this means that it will not be attempted. To the extent that (re-)entry into the industry remains feasible even if predation is successful, elimination of competitors is not the same as elimination of competition, and losses will be hard to recoup. This reasoning influenced the US Supreme Court in the landmark Matsushita case of 1986, with the majority judgement citing several Chicago School writings, and famously declaring that 'there is a consensus among commentators that predatory pricing schemes are rarely tried, and even more rarely successful'. ${ }^{3}$ Seven years later, in Brooke Group, the court opined that 'unsuccessful predation is in general a boon to consumers', 4 and laid down a stringent two-pronged test for identifying predatory pricing. The first condition to be satisfied was that the alleged predator's prices were below 'an appropriate measure of costs'. The court did not specify what measure would be appropriate, but both before and after this judgement, most lower courts employed the Areeda-Turner test, which requires the plaintiff to show that the defendant had charged a price below its average variable cost (AVC). This is relatively uncontroversial, because a price below AVC means that the firm is losing money on every unit it sells, although as seen below, it is difficult to apply in platform markets. The second condition laid down by the court was a 'dangerous probability, of recouping [the alleged predator's] investment in below-cost prices'. 5 This requires detailed analysis of the market and the industry, to provide a convincing demonstration that there are barriers to entry that will allow the alleged predator to recover its sacrifice of profits. This is hard to prove, and there have been no successful prosecutions of predatory pricing in the US since then.

The EU has not set such a high bar for predatory pricing cases. In 1991, the often cited $A K Z O$ decision of European Court of Justice (CJEU) held that while a price below AVC must always be regarded as abusive, even pricing above AVC may be abusive if the defendant had 'a plan to eliminate a competitor' ${ }^{6}$. The latter allowed for documentary and circumstantial evidence of predatory intent, which would not be decisive in the US. In its 1997 Tetra Pak decision, the CJEU again held that a:

\footnotetext{
${ }^{3}$ Matsushita Electric Industrial v Zenith Radio (1986) 475 US 574.

${ }^{4}$ Brooke Group Ltd v Brown \& Williamson Tobacco Corp (1993) 509 US 209.

$5_{\text {ibid. }}$

${ }^{6}$ Case C-62/86 AK AKZO Chemie v Commission of the European Communities (1991) ECLI:EU: C:1991:286, paras 71-72.
} 
price set below average variable cost must always be considered abusive. Predatory pricing may be penalised whenever there is risk that competitors will otherwise be eliminated without requiring additional proof that the undertaking in question has a realistic chance of recouping its losses. ${ }^{7}$

This position was firmly restated in 2009 in the Wanadoo case, in which the CJEU declared that 'demonstrating that it is possible to recoup losses is not a necessary precondition for a finding of predatory pricing ${ }^{8}{ }^{8}$ Thus, the EU employs a price-cost test that allows for prices above AVC to be regarded as abusive if predatory intent and the risk of elimination of competitors can be established, while prices below AVC are presumed to be predatory without requiring that recoupment be demonstrably probable. ${ }^{9}$

\section{The Game Theoretic Counter-Critique}

In the 1980s, the Chicago consensus was challenged by several models of 'rational predation', which employed the techniques of game theory with asymmetric information (one party knows something that another does not). In one version of this story, if the prey does not know what kind of firm it is confronting, then the predator can build up a reputation for competing aggressively, by setting 'irrational' loss-making prices in some markets or some periods. This can pay off if it deters later entrants, or rivals in other markets. Alternatively, if the dominant incumbent's cost is not known to its rivals, it might choose a low price to signal low costs, even if it actually has high costs. It can be shown that this possibility forces an incumbent who actually has low costs to set an even lower price. In another model with asymmetric information, the incumbent knows the characteristics of the market but the entrant does not. In this setting, the incumbent can reduce its price in such a way that the entrant cannot tell whether it has miscalculated demand or because the incumbent is engaging in predatory pricing. If the low price induces the entrant to infer a large enough probability on the former, it may quit, even if it may have withstood the latter. In another variant, directed against the Chicago contention that a predator should prefer merger to predation, predatory pricing may actually be a way of softening up the target as a prelude to a merger or takeover bid, so that it sells out at a lower price.

${ }^{7}$ Case C-333/94 P Tetra Pak International SA v Commission of the European Communities ECLI: EU:C:1996:436.

${ }^{8}$ Case C-202/07 P France Télécom SA v Commission of the European Communities (2009) ECLI: EU:C:2009:214, para 113.

${ }^{9}$ However, the ECJ's Post Danmark opinion of 2012 (Case C-209/10 Post Danmark A/S v Konkurrencerådet (2012) ECLI:EU:C:2012:172) suggests some rethinking that will allow the effects (both positive effects on efficiency, and negative effects on competition and consumers) of allegedly predatory prices to be considered as an alternative to intent, when predation cannot be presumed. 
Yet another version takes on Chicago by shifting the informational asymmetry to the capital market. If banks cannot observe firms' profits, they guard against bankruptcy by demanding higher interest rates from (or refusing to lend to) firms with lower equity. Predation then operates by reducing the value of the prey's equity, thereby tightening its external financial constraint. Finally, another model demonstrated that an incumbent may set a low price if this enables it to sell a larger volume of output which may involve short-term losses, but accelerates the process of cost reduction through 'learning by doing'. This assumes that there is a 'learning curve' relating costs to cumulative output over time. The reduced costs also diminishes the probability of (re-)entry by other firms, which was the Achilles' heel of static models of predatory pricing.

Although these game-theoretic models rehabilitated the possibility of rational predation, the implications for antitrust analysis are extremely complicated and hard to apply in specific cases. For one thing, the predatory price in all these models is not necessarily less than the incumbent's costs. Moreover, the likelihood of successful predation depends on the unobservable beliefs of the players and the counterfactual of 'non-predatory' pricing with accommodation of entry. The reputation models show that the characteristics of the market in which predatory pricing is alleged may not be relevant, since the predator may be willing to incur an irrecoverable loss in that market in order to acquire a fearsome reputation which will scare off rivals in other (geographic or product) markets. Unchallenged dominance in the latter markets in turn provides the deep pockets to finance the predatory campaign.

Even if an antitrust agency could somehow make a case that predation was intended, likely to succeed, and would permanently impair competition, it is not obvious that it should be penalized. The lower predatory price involves a trade-off: relative to the counterfactual, it makes consumers better off in the short run but worse off due to reduced competition in the long run. Matters become even more complicated if the predator permanently reduces its costs. Expanding sales so as to exploit a learning curve is a legitimate objective even without predatory intent, and even if it deters entry, is it any more objectionable than investing in new technology to reduce one's costs? Given all these complexities, and the fear that 'false positives' in predatory pricing cases would have a chilling effect on price competition, antitrust authorities have remained extremely reluctant to pursue such cases.

\section{The Indian Legal Framework}

Indian competition law remained oblivious of all these developments as long as the MRTP Act was in force from 1970 to 2009. The Act contained no explicit clauses on predatory pricing, but the MRTP Commission pronounced some manifestly erroneous orders, in which it held that low-priced imports from some foreign 
suppliers were predatory, even though they collectively supplied only a tiny share of the domestic market and there was no evidence that prices were below any measure of costs. ${ }^{10}$ Some rethinking was apparent in the 1999 report of the Raghavan Committee, which laid the foundations for India's Competition Act. In one of its many statements on the subject, it declared that 'predatory pricing is a discredited theory', which seemed to recognize the Chicago critique and US case law. But some members felt that it "is a pernicious practice warranting it being identified under the "per se illegal category". Ultimately, the Committee only recommended that 'it is better to treat predatory pricing as an abuse, only if it is unambiguously established and indulged in by a dominant undertaking. ${ }^{11}$ It prescribed a two-stage test resembling the Joskow-Klevorik test used in some American and British cases: first assess the market structure to determine whether a monopoly position attained by successful predation can be sustained, and then compare prices with costs.

These recommendations were incorporated and fleshed out in the Competition Act 2002, which explicitly included predatory pricing as a form of 'unfair or discriminatory' pricing, a prohibited abuse under Section 4, which pertains to the 'Abuse of a Dominant Position' (AoD). A dominant position is defined as 'a position of strength, enjoyed by an enterprise, in the relevant market, in India, which enables it to (i) operate independently of competitive forces prevailing in the relevant market; or (ii) affect its competitors in the relevant market in its favour.' Section 19(4) of the Act lays down 13 'factors', any or all of which the Commission 'shall have due regard to' in inquiring into whether an enterprise is dominant. These include market share, size and resources of the enterprise, size of competitors, and dependence of consumers on the enterprise. Criteria for defining the relevant product and geographical markets are also specified.

A predatory price is defined in Section 4 as 'a price, which is below the cost, as may be determined by regulations, of production of the goods or provision of services, with a view to reduce competition or eliminate the competitors'. The corresponding concept of cost, as specified in a Regulation adopted by the CCI shortly after the relevant sections of the Act came into force in $2009,{ }^{12}$ is 'average variable cost, as a proxy for marginal cost'. This is the Areeda-Turner test, but there is also a proviso 'that in specific cases, for reasons to be recorded in writing, the CCI may, depending on the nature of the industry, market and technology used,

\footnotetext{
${ }^{10}$ For a critical review of the MRTP Commission's orders, see Bhattacharjea (n 2).

${ }^{11}$ See ibid for a catalogue of the contradictory statements in the Report.

${ }^{12}$ The Competition Commission of India (Determination of Cost of Production) Regulations 2009 $<$ http://www.cci.gov.in/sites/default/files/regulation_pdf/cost_pro.pdf $>$. For an account of why the enforcement of the Act was delayed from 2002 to 2009, see Aditya Bhattacharjea, 'Of Omissions and Commissions: India's Competition Laws' (2010) 45 (35) Economic and Political Weekly $<$ http://www.epw.in/journal/2010/35/perspectives/omissions-and-commissionsindias-competitionlaws.html?0=ip_login_no_cache\%3Dcebfa4ec1d71c50d8eafed4a2d945fea>.
} 
consider any other relevant cost concept such as avoidable cost, long run average incremental cost, market value'. Each of these cost concepts is defined in the Regulation; the author returns below to the strange case of market value as a measure of cost.

This approach to predatory pricing was a definite improvement over that of the MRTP Act. By explicitly requiring evidence of dominance and below-cost pricing, the Competition Act comes close to the EU model and is insulated against the kind of wayward interpretations that the MRTP Commission felt free to devise. However, as the author has documented in an earlier article, ${ }^{13}$ the muddled wording of Section 4 of the Act (maladapted from Article 82-now 102-TFEU) is highly problematic, and its treatment of predatory pricing even more so. Unlike the adjacent sections on anticompetitive agreements and mergers, Section 4 of the Act does not require a test for anticompetitive effects, making it possible for the CCI to find any of the prohibited behaviours specified in the section (including predatory pricing) to be abusive per se. ${ }^{14}$ Fortunately, as the author has documented in an earlier paper, ${ }^{15}$ the CCI has set a high threshold for establishing dominance, and has treated it as a condition precedent to deciding on abuse, so this provision has remained untested.

Second, Section 4 carves out from the list of abusive practices any price (explicitly including predatory price) 'which may be adopted to meet the competition'. Despite the manifest origins of Section 4 in EU law, meeting the competition is not a defence that is permitted in the EU, as confirmed by the CJEU while upholding the judgement of the court of the First Instance in Wanadoo. ${ }^{16}$ Finally, the inclusion in the Regulation of 'market value' as a possible alternative measure of cost is incomprehensible. Section 2(c)(vi) of the Regulation offers an absurd definition: 'market value means the consideration which the customer pays or agrees to pay for a product which is sold or provided or can be sold or provided'-in short, the price. So by this measure, predatory pricing is pricing below the price! Third, Section 27 allows the CCI to order the breakup of a dominant firm even before it has abused its dominance - a dangerous weapon, which has fortunately not been deployed.

Before turning to platform competition, the author would like to summarize very briefly the sole CCI case that pertained to predatory pricing not involving platforms. In 2012, India's state-owned Oil and Natural Gas Corporation (ONGC) had floated a tender for providing a range of technical services for its oil and gas exploration

\footnotetext{
${ }^{13}$ Aditya Bhattacharjea, 'India's New Competition Law: A Comparative Assessment' (2008) 4 (3) Journal of Competition Law and Economics 629-632; Reprinted in Eleanor Fox and Abel Mateus (eds), Economic Development: The Critical Role of Competition Law and Politics (Edward Elgar 2011).

${ }^{14}$ This was first pointed out by Subhadip Ghosh and Thomas Ross, 'India's New Competition Law: A Canadian Perspective' (2008) Canadian Competition Record 23.

${ }^{15}$ Bhattacharjea (n 13).

${ }^{16}$ France Telecom (n 8), paras 50-61.
} 
activities for three years. (These presumably included services for its offshore drilling rigs - platforms of a very different kind). A losing bidder, HLS Asia, complained that Schlumberger had won the contract, covering almost all of ONGC's requirements, by quoting 'ridiculously' and 'unreasonably' low rates. However, HLS did not provide any data to establish that Schlumberger's bids were below its costs. Absent this evidence, the CCI held that no prima facie case could be made out, and closed the matter, without going into the questions of market definition and whether Schlumberger was dominant. ${ }^{17}$ This case, in conjunction with the other unsuccessful AoD cases discussed in the author's earlier article, suggests that the two prongs of the dominance plus price-cost test can be applied in either order, and that failing either prong would result in dismissal at the threshold.

\section{Platform Competition}

The economics of platform competition is based on the idea of externalities: the effects of self-interested actions taken by one party on other parties. Two-sided platforms generate a kind of reciprocal positive externality between two distinct groups: the benefits to a participant on one side of the platform depend on the size and composition of the group on the other side. ${ }^{18}$ In India, traditional village haats and cattle fairs have of course played this role for centuries, attracting buyers to locations where there are many sellers and vice versa. The distinguishing features of a networked platform are first, that it intermediates between heterogeneous groups whose members would benefit from being matched to particular members of the group on the other side; second, that the platform is operated commercially by a single economic entity, which can charge users on both sides an access or membership fee, and/or a fee per transaction. Shopping malls, stock exchanges, and multi-brand department stores fit this description. More recently, ICT has enabled e-commerce platforms of vastly greater scope. The most obvious examples are online retailers like Amazon, Flipkart, and Snapdeal, which give buyers access to a wider range of sellers, and sellers access to a larger number of buyers. Travel websites and on-line ticket-booking services for films and plays play the same role. (Consumers are usually not charged for access to most of these platforms, but it will be shown below that this is a profit-maximizing strategy that follows logically from the economics of platforms.)

Taxi service aggregators like Ola and Uber serve as platforms between individual taxi owners and customers by matching their locations. The more the taxis on one platform, the more quickly will a potential rider get a nearby vehicle willing

\footnotetext{
${ }^{17}$ HLS Asia Limited v Schlumberger Asia Services Ltd. (2012) Competition Commission of India, Case 80/2012, order dated 6 February 2013.

${ }^{18}$ Technically, this is what economists call an 'indirect network externality', but a full explanation would involve discussing the economics of networks and direct network externalities, which would take it too far afield.
} 
to go where she wants; the more the customers who access a particular service, the more taxi owners will want to sign up for that service. Credit card associations like Mastercard and Visa facilitate payments from consumers to sellers via their banks, but platform logic operates here as well: consumers are better off if more merchants accept the card that they carry, and merchants are better off if more consumers carry the card that they accept. The same goes for payment wallets like Paytm and Mobikwik.

This matchmaking function is also performed by advertising media. For example, newspapers are a medium for matching advertisers and readers who are consumers, television channels mediate between advertisers and viewers, radio channels between advertisers and listeners, and Google and Facebook between advertisers and users. All these serve as platforms, because advertisers on one side get access to a larger number of potential customers, and at least some consumers on the other side appreciate access to a wider range of advertisements. The platform function is different from the other services being provided (news, entertainment, search, or social networking), but generates all or most of the platform's revenue.

Yet another kind of platform is the operating system (OS) that runs a personal computer, laptop, smartphone, tablet or videogame console. The more the users of a particular OS, the bigger the market for applications (apps) that can run on it, and the more the apps, the more users who will choose a device that uses that OS. Examples that readily come to mind are Apple's iOS, Google's Android, and Microsoft's Windows, as well as Nintendo, PlayStation and Xbox. A very different example would be platforms that facilitate matching between men and women. Standard examples in Western countries are nightclubs and dating websites; more familiar Indian examples would be matrimonial agencies and websites. A site (real or virtual) that attracts more men will be more attractive to more women, and vice versa.

In each of these examples, participants on one side of the platform value not just the size but also the composition of the group on the other side. Consumers benefit from platforms that sell or advertise products and services more suited to their tastes and purchasing power; sellers benefit from exposure to potential customers who are more likely to buy their products. For taxi apps, the location of the vehicle and rider is paramount; for prospective dates, brides and grooms, other eligibility conditions obviously apply.

What does any of this have to do with predatory pricing? The answer should be evident to anyone who has used Facebook, FM radio, Google, no-fee credit or debit cards, travel websites, ride-hailing apps, or freely downloaded software: these are available for free, and therefore necessarily below cost - even if the cost of supplying an extra post, song, listing, electronic payment, or download is negligible. For most of the other examples given in the preceding paragraphs, the price to users on one side of the platform is only a fraction of the cost of production and supply. For example, the price of newspapers and magazines is often less than the cost of paper and printing. If the platform is to break even, such under-pricing must be 
recouped by 'overcharging' users on the other side. The externality described above results in a positive feedback effect between the number of users on the two sides. Success breeds success, with every increase in membership and usage on one side triggering an increase on the other side, further enhancing the attractiveness of the platform to users on the first side, and so on. Growth in the network's size also allows it to spread its fixed costs over a larger volume of transactions, resulting in orthodox economies of scale on the cost side. The feedback effect can also work in reverse, with any loss of customers on one side of a platform causing defections on the other side, recoiling on the first side, and so on in a downward spiral. This can result in the market 'tipping' towards domination by one or two platform firms, as all the named examples in the preceding paragraphs show.

Once entrenched with a large number of users on both sides, a platform is hard to dislodge. A new entrant must necessarily begin with substantial investment and fewer users, and will therefore not attract more, unless it is willing to incur ruinous losses. The user-specific data (on shopping, commuting, or social networking patterns) amassed by an incumbent platform is also not available to potential rivals, making it a powerful barrier to entry, or 'incumbency advantage'. Platforms can use this data to provide users with suggested matches that suit their tastes, but also to charge them personalized prices based on their observed willingness to pay, which can help with recoupment. The combination of below-cost pricing, recoupment, elimination of competition, and domination by one or two firms, makes this scenario appear suspiciously like predatory pricing.

This is where the economics of two-sided platforms tells us that there are other considerations at work. What is happening here is a standard response to an externality problem. Economic actors do not appropriate the benefits of any positive externalities that their actions generate, and need to be induced to perform more of those actions: in this case, joining and actively using a platform so as to induce participation on the other side. In order to be viable at all, the platform must have a critical mass of users on both sides. Therefore, it charges less from those on one side than it would have in a traditional 'one-sided' market, sometimes to the point of providing the service for free or even subsidizing it, as in the case of credit cards that offer 'cash-back' deals or reward points proportionate to the value of transactions.

The profit-maximizing price on each side of the platform therefore depends not only on the marginal costs and price-sensitivity (elasticity) of demand on that side, but also the costs and elasticity on the other side, as well as the strength of the demand externalities between the two sides. The resulting price structure may well involve below-cost pricing on one side of the platform and above-cost pricing on the other, so the prices on the two sides should not be seen in isolation from each other. Such asymmetric pricing may be a feature of a platform regardless of the presence or absence of rivals. Yet, the feedback effects discussed above set up a tendency towards a 'winner takes all' outcome, even if this was not the intention of the firm's pricing behaviour. A price below cost cannot therefore be regarded as 
predatory. On the other hand, a firm with predatory intent may indeed exploit a network externality by charging a low price on one side. But this price may have an exclusionary effect even if it is not below cost. Standard price-cost tests, therefore, are misleading and may result in both false positives and false negatives. A relatively recent strand of antitrust thinking looks at the personalized data that the platforms acquire from their users as the hidden 'price' of their services; it is difficult to see how such data can be valued for a price-cost comparison.

Apart from the complications that platform economics creates for price-cost tests, it also needs to be considered that some forces work against complete monopolization by a single platform, countervailing the inherent 'winner takes all' tendency described above. First, there may be diseconomies of scale due to congestion. This is evident in the case of brick and mortar platforms that are limited by capacity, such as nightclubs, malls, and stock exchanges. But congestion may also occur in virtual platforms with virtually limitless capacity, as participants find it increasingly difficult to find a match when the crowd on the other side becomes too large. Therefore, multiple platforms can cater to different groups so as to allow for targeted matching. Such market segmentation can be vertical, with different platforms serving consumers with different incomes (e.g. magazines, stores and websites that feature luxury products and services as against those which cater to a mass market). Or it can be horizontal, with platforms specializing in different locations, tastes or needs (e.g. malls or clubs in different parts of a city; TV channels specializing in different kinds of programming; newspapers catering to readers with different preferences; websites specializing in different kinds of products or services; Facebook for social networking $\mathrm{v}$ LinkedIn for professional networking). Second, the scope for one firm to take over the market is limited if users find it convenient to patronize more than one platform, or if they can easily switch to a rival platform, as with credit cards, nightclubs, newspapers or television channels. (This is technically known as 'multi-homing'). For both reasons, different platforms can profitably co-exist.

On the other hand, depending on the nature of the industry and the platform, these countervailing forces may be too weak to offset the 'winner takes all' dynamics. Multi-homing could involve additional costs for users (such as paying multiple membership fees, visiting different locations, or learning different software commands). A single online platform can itself mitigate the congestion problem by building in search filters or an algorithm that helps different types of users to find matches in different categories, locations or price ranges, with lower search costs. This will reinforce the tendency towards a winner takes all outcome. But even if one platform ultimately dominates a particular market, it is not clear that users are worse off than with many competing platforms. If the dominant platform is well designed, users get access to a wider range of potential matches without the costs of multi-homing. Further, as compared to multiple competing platforms, a platform monopolist may well impose higher charges on the seller-facing side, enabling it to charge lower prices on the consumer-facing side. For many antitrust scholars, especially in the US, consumer welfare (in the form of lower prices) is the standard 
by which to judge market outcomes. By this standard, market concentration in a single platform is not necessarily harmful. ${ }^{19}$

In recent years, several American antitrust scholars have begun to question whether the consumer welfare standard, and many other long-established antitrust principles, are relevant or desirable in dealing with giant ICT-based firms. Several such scholars are cited in a blockbuster paper by Lina Khan. ${ }^{20}$ She argues persuasively that Amazon's incredibly low prices, leading to losses sustained for years at a stretch, betray a business strategy that privileges growth and market dominance over profit, at least over a very long horizon. She calls for abandoning the recoupment standard, and argues that the harmful effects of Amazon's behavior are felt in related markets that it has penetrated, quality degradation, reduction of choice, and price discrimination. Moving beyond the domain of consumer welfare, she draws on the legislative history of the American antitrust statutes to argue eloquently for a return to concerns with market structure and the competitive process rather than its outcome in terms of prices, and sensitivity to issues of dispersal of economic and political power. She recommends that predatory pricing by a dominant firm should be treated as presumptively illegal, subject to a few 'business justifications' including 'meeting the competition'. Interestingly, this is the approach of Section 4 of India's Competition Act, although the CCI has repeatedly rejected a definition of dominance based only on market share, which is what Khan advocates. Her paper is part of a growing literature that questions established antitrust principles, harking back to the early years of US antitrust and calling for bringing inequality and the concentration of economic and political power back into focus. This literature has little to say about predatory pricing, so a few remarks are consigned to a footnote. ${ }^{21}$

\footnotetext{
${ }^{19}$ Strictly speaking, economic theory judges outcomes in terms of total or 'social' welfare, defined as the sum of producer and consumer surplus, with the latter taking into account variety and quality in addition to price. But this is nearly impossible to calculate in actual cases, so the consumer welfare standard is used in practice. This standard has very recently come under fire from a vocal section of the American media and legal scholars. This debate is briefly discussed below.

${ }^{20}$ Lina M. Khan, 'Amazon's Antitrust Paradox' (2017) 126(3) Yale Law Journal 710.

${ }^{21}$ See also William A. Galston and Clara Hendrickson, 'A policy at peace with itself: Antitrust remedies for our concentrated, uncompetitive economy' (Brookings Institution Report, 5 January 2018) <https://www.brookings.edu/research/a-policy-at-peace-with-itself-antitrustremedies-for-our-concentrated-uncompetitive-economy/> accessed 22 January 2018. The title of their paper, as well as Khan's (n 20), allude to Robert Bork, The Antitrust Paradox: A Policy at War with Itself (New York: Basic Books 1979), widely regarded as the foundational text of the Chicago critique. Mainstream antitrust economists are unmoved by this reopening of an apparently settled debate. Shapiro (n 1) makes a qualified case for more active antitrust enforcement while retaining consumer welfare as the guiding principle, and avoiding the trap of condemning firms for being successful or growing too big. While he agrees that concentration of political power, inequality and unemployment are very important issues, he believes that antitrust is not the right policy with which to tackle them. In earlier work, the author has shown how antitrust in most developed countries was motivated by a variety of objectives that would nowadays be regarded as non-economic, and the economic efficiency-based approach (based on maximizing social or
} 


\section{The Radio Taxi Wars}

The author now turns to a case study of how Indian competition law has begun to get to grips with allegations of predatory pricing by platforms in a particular sector of the economy in which ICT has come to play a crucial new role. As the discussion above makes clear, ICT tools have vastly increased the power of platforms, by allowing them to reach huge numbers of users on both sides, collect the information relevant to each one's idiosyncratic demand and supply, and facilitate matching, logistics and payments. This has given rise to a new business model-taxi aggregation or ride-sharing - which has disrupted a venerable old industry. Unlike most ICT-enabled platforms, smartphones with GPS are a key additional element of this model, because real-time tracking of each other's location by taxi drivers and potential riders is crucial. The rapid penetration of smartphone usage in India, at least among the urban population, has sown the seeds of disruption. ${ }^{22}$

Traditionally, as in other countries, taxis in India were owned by individuals and could be hailed from a stand or off the road. From around 2007, a number of radio taxi companies began operating in the major Indian cities, with call centres which despatched their own taxis to riders on the basis of bookings via telephone or internet. From 2011, this business model was severely disrupted by the entry of taxi aggregators like Ola and Uber, who did not own any vehicles but only provided a platform to connect owner-drivers with potential passengers based on GPS-enabled smartphones that identified their locations. The aggregators' algorithms set the fares for each trip, and unlike tariffs for traditional taxis, these could be calibrated in real time to reflect the supply/demand balance for rides. In 2015, Meru, one of the more successful radio taxi operators whose business had been badly affected, filed separate cases with the CCI, alleging that Uber in Delhi and Kolkata, and ANI Technologies (owners of the Ola brand) in Bengaluru, were engaged in predatory pricing. Another radio taxi operator, Mega Cabs, filed a similar case against ANI in regard to the Delhi market, as

consumer surplus) is of relatively recent vintage. Author suggested that competition policy in developing countries could address distributional issues by competition agencies initiating more vigorous suo moto inquiries into markets for goods and services consumed by the poor, instead of allowing their dockets to be swamped by clashes between corporate giants. See generally, Aditya Bhattacharjea, 'Who Needs Antitrust?: Or, Is Developing-Country Antitrust Different? A Historical-Comparative Analysis' in Daniel Sokol, Thomas K. Cheng and Ioannis Lianos (eds), Competition Law and Development (Stanford University Press 2013).

${ }^{22}$ India's smartphone revolution is impacting many other industries. See generally, Hemant K. Bhargava, David S. Evans and Deepa Mani, 'The Move to Smart Mobile and Its Implications for Antitrust Analysis of Online Markets' (2016) 16 UC Davis Business Law Journal 157. The authors forcefully argue that antitrust principles developed for static markets are inapplicable to such rapidly evolving markets. 
did three individual auto-rickshaw drivers. (Ola also provided aggregation services for auto-rickshaws. $)^{23}$ The author summarize below the essential features of these cases.

In all five cases, the informants claimed that the 'Opposite Parties' (Ola or Uber) were dominant because each had within a few years captured over $50 \%$ of the relevant market. Allegedly, this was because they were backed by vast amounts of venture capital and private equity funding that enabled them to run their services at a loss, offering very low fares to passengers and multiple incentives to drivers. ${ }^{24}$ There were disputes over the exact definition of the relevant markets and the reliability of the market share data submitted by the informants, but the outcome of the cases did not depend on these issues. In every case, the CCI found that there was adequate evidence of vigorous competition between Ola and Uber, with several other radio taxi services also present in each market. Evidence of fluctuating market shares showed that 'the competitive landscape in the relevant market is quite vibrant and dynamic'. ${ }^{25}$ Thus no case of dominance was made out, and the CCI did not have to make a determination on the question of predatory pricing, although on that point Uber had been up front about network effects, claiming that its price reduction was 'not to indulge in unhealthy competition but to bring more and more cabs and customers to its network and to increase the value of the network'. ${ }^{26}$ In the slightly different case initiated by the Delhi auto-rickshaw drivers, their counsel argued that the relevant product market included all 'paratransit services' including traditional taxis and auto-rickshaws. But the CCI held that 'owing to the difference in comfort, time taken ... buying power of the consumer (rider) etc.', ${ }^{27}$ auto-rickshaws operated in a different product market as compared to radio taxis, and less than $20 \%$ of Delhi's auto-rickshaws operated on the Ola network. Therefore, here again Ola was not dominant. (Uber was not present in the auto-rickshaw segment.)

\footnotetext{
${ }^{23}$ Meru Travel Solutions Pvt Ltd (MTSPL) v Uber India Systems Pvt Ltd (2015) Competition Commission of India, Case No. 81 of 2015, order dated 22 December 2015 (Kolkata); Mega Cabs Pvt Ltd v ANI Technologies Pvt Ltd (2015) Competition Commission of India, Case No. 82 of 2015, order dated 9 February 2016; Meru Travel Solutions Pvt Ltd v Uber India Systems Pvt Ltd and Others (2015) Competition Commission of India, Case No. 96 of 2015, order dated 10 February 2016; Mr Vilakshan Kumar Yadav and Ors. v ANI Technologies Pvt Ltd (2016) Competition Commission of India, Case No. 21 of 2016, order dated 31 August 2016 (all three Delhi); Fast Track Call Pvt Ltd and Meru Travel Solutions Pvt Ltd v ANI Technologies Pvt Ltd Competition Commission of India, Case No. 21 of 2016, Cases No 6 and 74 of 2015, order dated 19 July 2017 (both Bengaluru; another radio taxi company, Fast Track, had separately submitted information against ANI/Ola. Finding similar allegations in both cases, the Commission clubbed them for investigation and disposal).

${ }^{24}$ Although the bulk of Khan's paper is taken up by her documentation of Amazon's behavior, Uber is also mentioned (Khan (n 20) 786-787), as following a similar predatory strategy, with sustained heavy losses financed by investors.

${ }^{25}$ Meru Travel Solutions Private Limited (Case No. 96) (n 23), para 24.

${ }^{26}$ ibid 15 , emphasis added.

${ }^{27}$ Mr Vilakshan Kumar Yadav and Ors. (n 23), para 14.
} 
In one of the Delhi cases, Meru appealed to the Competition Appellate Tribunal (COMPAT), which disagreed with the CCI's narrow definition of the relevant geographical market. It pointed out inconsistencies in the CCI's reliance on the market share data given in different survey reports. It also held that under Section 19(4), dominance should not be established based on market share alone, but the high market shares ascribed to Uber in the survey report submitted by Meru could not be ignored. Regarding pricing, it remained agnostic:

\begin{abstract}
Aggregator-based radio taxi service is a relatively new paradigm of public transport in Indian cities... Reportedly, it has done wonders to consumer satisfaction in whichever city it has started. Therefore, it cannot be said definitively that there is an abuse inherent in the business practices adopted by operator such as respondents [Uber,] but the size of discounts and incentives show that there are either phenomenal efficiency improvements, which are replacing existing business models with the new business models or there could be an anticompetitive stance to it. $^{28}$
\end{abstract}

COMPAT reopened the case, ordering an investigation by the Director General (DG) of the CCI. But Uber immediately appealed to the Supreme Court, on the grounds that COMPAT could only order an investigation if it found a prima facie case against Uber, and that no such case could be made out because Uber was not dominant in the relevant market. In January 2017, the Supreme Court restrained the CCI from carrying out the investigation until further orders. Further hearings took place in March 2017, but no further developments in this case have been reported up till the time (January 2018) that this chapter was completed.

In four of the five cases reviewed here, the CCI found no dominance and hence no prima facie case and closed the matter without ordering an inquiry by its DG. The author would like to summarize at somewhat greater length the fifth case, in which Meru and Ola faced off with regard to the Bengaluru market. Even though its final decision was ultimately the same as in the other four cases, in this instance the CCI did find a prima facie case of abuse, ordered a DG investigation, considered more arguments going beyond market shares, and also discussed the economics of platform competition and the issue of unequal access to financial markets. ${ }^{29}$ Presumably, if the Supreme Court allows the investigation in Meru $v$ Uber to proceed, that case will follow a similar trajectory to Meru v Ola.

In Meru $v$ Ola, the CCI accepted the contention of the informants that the relevant market was the market for radio taxi services in Bengaluru. It rejected Ola's argument that it was not a taxi service provider, but only a technology software service provider or aggregator, enabling taxi drivers to connect with potential passengers and facilitating payments. Notwithstanding that Ola, unlike the rival radio taxi services, did not own the taxis that operated on its platform, it did fix their prices and offer their services, which consumers treated as functionally

\footnotetext{
${ }^{28}$ Meru Travel Solutions Pvt Ltd v Competition Commission of India, Uber India Systems Pvt Ltd \& Ors (2016) Appeal No. 21/2016, order dated 7 December 2016, para 18.

${ }^{29}$ Fast Track Call Pvt Ltd and Meru Travel Solutions Pvt Ltd (n 23).
} 
substitutable with those of the rival operators. Regulatory authorities also treated aggregators as radio taxi service providers. The CCI concluded that having a different business model did not imply that Ola operated in a different market.

The bulk of the CCI's analysis dealt with the question of whether Ola was dominant in the market thus defined. The fleet sizes registered by the different platforms were not appropriate for market share calculations, since taxi owners could register with different platforms; instead the number of trips was taken as the relevant indicator. Four years after it commenced its Bengaluru operations in 2011, Ola's share of the number of taxi trips exceeded $60 \%$, which according to the informants created a presumption of dominance. Conversely, Meru's share fell from 60 to 6-7\%, and the other traditional companies were driven down to even less. But the CCI refused to accept this as evidence of Ola's dominance. It pointed out that market share was only one of the indicators provided in the Act for assessing dominance, and in new high-tech industries high market shares could be ephemeral. The CCI highlighted the fact that Uber, which entered in 2013, had acquired a share of nearly a third by 2015 , providing effective competition to Ola, whose share actually dipped. The erosion of the older operators' shares was 'more attributable to the expansion of the consumer base in the market than them being deprived of the demand which they were serving before'. ${ }^{30}$ All but one of the older operators had in fact witnessed an absolute increase in the number of trips.

The CCI then gave a nice summary of the economics of network effects in two-sided platforms ${ }^{31}$, but it did not agree with the informants that these constituted barriers to entry. It pointed out that the network effects had not been strong enough to deter the entry and rapid expansion of Uber. It also pointed out that both drivers and riders could multi-home, switching easily between Ola and Uber. This 'constrains the power of the platforms to act independently of the market forces' ${ }^{32}$ Entry conditions for platforms were also more favourable than for traditional taxi services, because platforms did not need to invest in large fleets of vehicles. The CCI also disagreed with the informants that Ola's access to huge finances from foreign venture funds constituted an entry barrier. It pointed out that many start-ups in various high-tech sectors with network effects had attracted financing. New business models and technologies were rapidly displacing older ones.

The CCI refused to be swayed by the informants citing of its order in $M C X v$ $N S E$, in which it had suggested that predatory pricing itself could evidence of dominance. It referred approvingly to the holistic approach of the Act, which did not allow for a firm's conduct to be accepted as evidence of dominance in the absence of other factors. The informants had also argued that the absence of further entry after Uber indicated lack of competition, but the CCI did not agree. It emphasized that competition analysis required assessment of the competitive

\footnotetext{
${ }^{30}$ ibid, para 81 .

${ }^{31}$ ibid, paras 89-92.

${ }^{32}$ ibid, para 94 .
} 
process, not a count of the number of firms. A table of average monthly margins over the period of investigations showed that it was Uber that had initiated the strategy of pricing below costs, with Ola following nine months later. Finally, the CCI made short work of the informant's argument that Ola and Uber could be held to be jointly dominant. Apart from citing the language of the Act itself, the CCI pointed out that in 2012, an amending Bill had been tabled in the Lok Sabha (Lower House of Parliament) in order to introduce the concept of joint dominance, thereby showing that Parliament was aware that it was absent in the Act. The Bill lapsed when the Lok Sabha was dissolved in 2014 before it could be passed.

The CCI's conclusions on dominance deserve to be reproduced in full:

In conclusion, based on collective consideration of the facts that the competitive process in the relevant market is unfolding, market is growing rapidly, effective entry has taken place thereby leading to gradual decline in [Ola's] market share, entry barriers are not insurmountable, there exist countervailing market forces that constrain the behaviour of OP and the nature of competition in dynamic, innovation-driven markets, the Commission is of the considered view that [Ola's] dominance in the relevant market remains unsubstantiated. ${ }^{33}$

Since in the CCI's jurisprudence, establishing dominance has been (in most cases) a hurdle that has to be crossed before addressing the allegation of predatory pricing, this conclusion was sufficient to dispose of the case against Ola. But the CCI nonetheless devoted the last few paragraphs of its order to a brief discussion of pricing strategy. It was clearly impressed by the $1900 \%$ increase in radio taxi trips during the 40-month period of investigation, attributing it not only to the reduction in transaction costs made possible by the platform technology, but also the 'abysmally low prices' of Ola and Uber which had 'revolutionised the taxi market' ${ }^{34}$ Significantly, it acknowledged that

[T]he Commission does not fully disagree with the Informants that the low prices of [Ola] are not because of cost efficiency, but because of the funding it has received from the private equity funds. But as discussed above, there is no evidence that the access to such funding was inequitable and that the market for financing was not competitive and had aberrations. Moreover, it was their penetrative pricing strategy that facilitated them to garner high market shares in short span of time as well as develop the networks to a size that could provide sufficient positive externalities to the participants of the network. ${ }^{35}$

The CCI concluded that 'it is difficult to determine with certainty the long-term impact of this pricing strategy as the market is yet to mature', and expressed its reluctance 'to interfere in a market which is yet to fully evolve'. In any case, there was a 'statutory compulsion of non-intervention' because dominance could not be established. $^{36}$

\footnotetext{
${ }^{33}$ ibid, para 105.

34 ibid, para 121.

${ }^{35}$ ibid, para 122.

36 ibid, para 123.
} 
This order of the CCI in Meru v Ola may be appealed, as was the order in Meru $v$ Uber, which resulted in COMPAT'S directive to investigate the issue of dominance. However, the taxi wars entered a new phase in October 2017 when Meru initiated a fresh round of litigation before the CCI by alleging that acquisition of large equity stakes in both Ola and Uber by SoftBank would affect their pricing decisions jointly. This raises multiple possibilities. The common shareholder could be seen to facilitate a horizontal agreement or understanding on price-fixing, which would be presumptively illegal under Section 3(3) of the Act. Or, if it could be established that SoftBank's shareholding is sufficient for it to exercise control over both the firms, then they could be a 'group' as defined in the Act. This would allow Meru to cross the hurdle of establishing their joint dominance in the relevant markets, clearing the path to an inquiry into an exclusionary pricing strategy under Section 4. Even if no such common understanding or control can be established, if either Ola or Uber is individually found to be dominant in one of the metros after a fresh investigation, the question of SoftBank's liability for the conduct of its portfolio firms might arise. ${ }^{37}$

Meanwhile, the two giants, Ola and Uber, continue to slug it out, incurring heavy losses, being kept afloat only by periodic infusions of venture capital. Presumably, armed with the huge amount of data they have gathered on individuals' commuting patterns, the promoters of each one (and their investors) have worked out the pricing structure that they would implement if the other one gives up and exits, and on that basis have calculated that they will be able to recoup their losses. While the CCI is not required to establish recoupment, it will have to look into price-cost margins. How will it distinguish between 'phenomenal efficiency improvements' and anticompetitive behaviour, both of which the COMPAT allowed for a while ordering the investigation? While prices can be inferred from reported revenues, the AVC for such operators would have to be constructed from data on commissions and incentives given to drivers. What the equilibrium monopoly pricing structure might be, and whether consumers would be worse off if only one aggregator is left standing, is probably beyond any antitrust agency's ability to predict. How far the CCI can venture in such cases is also open to question, given that Section 4 of the Competition Act does not require an assessment of effects on competition. But these issues will arise only if the Supreme Court allows the investigation into Uber's dominance to proceed, and the CCI either finds Uber to be dominant or is persuaded by the new arguments based on common shareholding. Meanwhile, the COMPAT has been wound up, and all appeals will now go the overburdened National Company Law Appellate Tribunal, which has no experience in competition matters, and then to the Supreme Court. Resolution of these issues seems a long way off, by which time technologies, business models, and commuting habits of the public may have changed significantly.

\footnotetext{
${ }^{37}$ For a discussion of the antitrust analysis of the role of common shareholding in anticompetitive practices of portfolio firms (written before SoftBank invested in Uber), see Smriti Parsheera, Ajay Shah and Avirup Bose, 'Competition Issues in India's Online Economy' (2017) National Institute of Public Finance and Policy Working Paper No. 194 <http://www.nipfp.org.in/media/ medialibrary/2017/04/WP_2017_194.pdf>.
} 


\section{Conclusion}

The economic analysis of predatory pricing has gone through several phases. If the Chicago critique cast doubt on the very rationality of such a strategy, then the game-theoretic counter-critique rehabilitated it theoretically but gave few practical insights into how to identify it in real-world cases. The newer literature on platform competition has further muddied these waters, showing that there is no simple way to prove predatory pricing, much less to condemn it. Indian competition jurisprudence, having gone completely off the rails in the MRTP era, is now cautiously trying to deal with some of these issues in the ongoing legal battles between old and new model radio taxi operators.

It is difficult at this stage to provide any general principles on how to proceed in such cases. ${ }^{38}$ What emerges from the successive doctrinal phases in antitrust thinking that the author surveyed above is that assessment of predatory pricing in platform competition is very complicated and should be conducted case by case, taking into account both positive and negative effects which may differ from industry to industry. This requires what is called the 'rule of reason' in antitrust jurisprudence. Such an approach requires careful fact-finding and analysis. But given the rapidly unfolding dynamics of platforms, the complexity of arguments on both sides, and the ability of such firms to withhold data and hire top lawyers to delay proceedings, the damage may be done and the platform fully entrenched before the case is decided. On the other hand, early intervention by a competition agency could prematurely kill off a promising new business model which might eventually prove beneficial for society. Unleashing the agency's weapon of the last resort, the power to break up a dominant firm, would be self-defeating: as the Economist put it recently, 'a full-scale break-up would cripple the platforms' economies of scale, worsening the service they offer consumers. And even then, one of the Googlettes or Facebabies would eventually sweep all before it as the inexorable logic of network effects reasserted itself. ${ }^{39}$

\section{Postscript}

As the final proofs of this chapter were being reviewed, the CCI pronounced a combined order disposing of four very similar 'informations' filed by Meru against Ola and Uber regarding their conduct in Hyderabad, Chennai, Mumbai and Kolkata (Cases 25-28 of 2017, order dated 20 June 2018). Meru repeated many of the arguments it had advanced in the cases discussed above in Part 6, and the

\footnotetext{
${ }^{38}$ Parsheera, Shah and Bose (n 37) gave some interesting suggestions on how the CCI should deal with competition issues in network markets, but the author does not think they can be accommodated within the scheme of the Competition Act.

39، Taming the Titans' The Economist (20-26 January 2018) 11.
} 
Commission rejected them on the same grounds as before. But, as mentioned on page 228 above, Meru also advanced the new argument that Ola and Uber are now dominant as a group because common investors like SoftBank own shares in both companies. The CCI's order acknowledged that both academics and competition authorities have recently assessed various 'theories of harm' that could arise out of common ownership, but the theoretical and empirical literature does not give any grounds for concluding that such ownership would always have an anticompetitive effect. Even if Ola and Uber could be held to be dominant as a group on the basis of common ownership, the Commission pointed out that there was inadequate evidence of abuse of dominance. Therefore, it held that the facts do not at present establish a prima facie case of violation of the Competition Act, and closed the case. However, it warned that it would keep a close eye on the firms, and take action if common ownership results in anticompetitive effects in future. Network effects and platform competition did not figure significantly in this order.

Open Access This chapter is licensed under the terms of the Creative Commons Attribution 4.0 International License (http://creativecommons.org/licenses/by/4.0/), which permits use, sharing, adaptation, distribution and reproduction in any medium or format, as long as you give appropriate credit to the original author(s) and the source, provide a link to the Creative Commons license and indicate if changes were made.

The images or other third party material in this chapter are included in the chapter's Creative Commons license, unless indicated otherwise in a credit line to the material. If material is not included in the chapter's Creative Commons license and your intended use is not permitted by statutory regulation or exceeds the permitted use, you will need to obtain permission directly from the copyright holder.

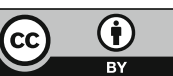

